\title{
Perkembangan Sanksi Administratif \\ Dalam Penguatan Perlindungan Lingkungan \\ Terkait Eksploitasi Sumber Daya Alam \\ (Studi Kasus : Sektor Perkebunan, Pertambangan, dan Kehutanan)
}

\author{
Grahat Nagara ${ }^{1}$
}

\begin{abstract}
Abstrak
Walaupun sanksi administratif sebagai salah satu instrumen dalam model command-and-control seringkali merupakan satu aspek yang banyak dikritik, dalam perkembangannya justru menyimpan peluang untuk memperkuat upaya perlindungan lingkungan hidup. Beberapa yang akan dibahas dalam tulisan ini termasuk, penguatan sanksi administratif dengan sanksi pidana, maupun dengan memperkenalkan sanksi denda dan pemulihan. Untuk membaca potensi penguatan yang terjadi di Indonesia dengan perkembangan sanksi administrasi, pendekatan yuridis-normatif dilakukan untuk mencermati perumusan sanksi administratif terkait perlindungan lingkungan hidup dalam kegiatan usaha sektor sumber daya alam. Tulisan ini menemukan bahwa meskipun perkembangan kebijakan perlindungan lingkungan hidup terjadi, termasuk juga melalui penguatan sanksi administratif, upaya tersebut masih dapat dikatakan belum memadai. Khususnya karena belum dapat ditemukan upaya serius untuk memperhatikan kontribusi rumusan sanksi yang akurat untuk meningkatkan efektivitas penegakan hukum dalam perlindungan lingkungan. Berdasarkan temuan itu, penulis menekankan pentingnya pembenahan hukum administratif khususnya dalam hal pengaturan sanksi administrasinya.

Kata kunci: command-and-control, penegakan hukum administrasi, perlindungan lingkungan hidup.

1 Peneliti Hukum Yayasan Auriga Nusantara, Pengajar di Departemen Administrasi Negara, Fakultas Ilmu Administrasi, Universitas Indonesia.
\end{abstract}




\section{Abstract}

While administrative sanction in command-and-control model often criticized, in the contemporary legal issues, it provide various opportunities to strengthen environmental protection. Some of which explored in this paper including on how it could be combined with criminal sanction and by introducing complementary sanction such as fines and environmental restoration. To understand the potential effort to strengthen the administrative sanction in Indonesia, a normative approach will be used to examines administrative sanctions text in Indonesian legal framework of environmental protection especially in related with natural resource extraction activities. The article found that despite common trends of development in environmental protection also occurred in Indonesia, some of the effort to strengthen the administrative sanction is still inadequate. Particularly, most of them has not been seriously arranged to encourage a precise and proper sanction to address the effectivity of enfironmental protection law enforcement. Based on the findings, the paper recommend the substantial urgency in reforming the administrative law mostly imperative on its administrative sanction.

Keyword: command-and-control, adminitstrative law enforcement, environmental protection.

\section{Pendahuluan}

Dengan berbagai perkembangan hukum administrasi yang juga mendorong mekanisme insentif ekonomi, penegakan hukum administrasi dengan dimensi penaatan berbasis ancaman (command and control) seringkali dilematis, selain dianggap tidak efektif dan efisien, bahkan disebutkan cenderung tidak memiliki legitimasi demokratis yang memadai ${ }^{2}$. Tidak efisien karena penaatan hukum administrasi yang bersifat cenderung represif dinilai secara inheren akan menyebabkan biaya sosial yang jauh lebih tinggi ketimbang manfaatnya. Selain itu, penerapan sanksi administrasi khususnya yang bersifat moneter sering tidak sebanding dengan biaya penegakan hukumnya itu sendiri, bahkan seringkali

2 Peter Z. Grossman dan Daniel H. Cole. “When is Command-and-Control Efficient? Institutions, Technology and the Comparative Efficiency of Alternative Regulatory Regimes for Environmental Protection." Wisconsin Law Review (1999), hal. 887. Dapat diunduh melalui http://www.repository.law.indiana.edu/facpub/590. Dalam artikel tersebut, Cole dan Grossman mengutip pendapat Richard B. Stewart dalam, "Models for Environmental Regulation: Central Planning Versus Market-Based Approaches", 19 B.C. Environmental Affair Law Review (1992), hal. 547. 
insentif untuk mendapatkan sumber daya alam secara ilegal jauh lebih tinggi ketimbang denda yang harus dibayar apabila terdeteksi oleh pemerintah ${ }^{3}$.

Catatan terhadap penggunaan sanksi administrasi juga dibandingkan dengan instrumen pidana. Kemampuan untuk menyediakan efek jera terhadap pelaku, merupakan salah satu alasan keunggulan sanksi pidana dibanding sanksi administratif yang dianggap hanya mengutamakan untuk terhentinya perbuatan ${ }^{4}$. Keterbatasan sanksi dalam penegakan hukum administratif juga menjadi persoalan dalam upaya untuk mencegah kerusakan lingkungan ${ }^{5}$. Lebih rinci lagi, Faure dan Visser menyatakan bahwa dibanding sanksi pidana, sanksi administratif seringkali bermasalah dalam hal $\left.{ }^{6}: 1\right)$ bahwa hukum administrasi tidak mengenal penghukuman atau sanksi non moneter, penegakan non moneter memerlukan hukum pidana yang berjalan efektif; 2) bahwa hukum administratif seringkali terlalu banyak bertendensi untuk mengedepankan kepatuhan yang persuasif ketimbang mencegah perbuatan yang dilarang. Kondisi ini menjadi insentif ex-ante yang salah bagi pelaku perusakan lingkungan untuk mengabaikan regulasi pada batas-batas tertentu; 3) hukum administrasi akan lebih efektif jika ada dukungan sanksi pidana, sehingga dapat memperkuat negosiasi dalam penegakan hukum administratifnya.

Catatan kritis terhadap penegakan hukum administrasi sendiri masih dalam perdebatan dan belum tentu relevan lagi dengan perkembangan hukum yang ada saat ini. Penelitian lain justru menyatakan bahwa penegakan hukum administrasi masih mampu menjadi instrumen untuk mengendalikan aktivitas yang melanggar hukum - termasuk perusakan lingkungan ${ }^{7}$. Kemudian dijelaskan juga oleh Ogus

3 Sofia R. Hirakuri, Can law save the forest?: lessons from Finland and Brazil, (CIFOR: Bogor, Indonesia, 2003), hal. 85.

4 Philipus M. Hadjon, et.al., Pengantar Hukum Administrasi Indonesia, (Gajah Mada University Press: Yogyakarta, 2015), hal. 239. Lebih lanjut akan dijelaskan di bagian pembahasan.

5 Michael G. Faure, Koopmans Ingebord, dan J. C. Oudijk. "Imposing criminal liability on Government Officials under environmental law: a legal and economic analysis". Loyola of Los Angeles International Comparative Law Journal (1996), hal.529-569.

6 Michael G. Faure dan Marjolein Visser. "Law and economics of environmental crime: a survey." Pridobljeno 10 (2003), hal.15-20.

7 Cole dan Grossman, loc.cit., hal. 936. Lihat juga Neil Gunningham. “Beyond compliance: next generation environmental regulation." Regulatory Institutions Network, ANU, artikel ini dipresentasikan pada Current Issues in Regulation: Enforcement and Compliance Conference (2002), hal. 2 dan 23. 
dan Abott bahwa seringkali penegakan hukum administratif memiliki prosedur yang lebih ringkas ${ }^{8}$, lebih murah, sehingga lebih memadai untuk mencapai tujuan penegakan hukum itu sendiri ketimbang pidana9. Beberapa proponen hukum administratif bahkan lebih jauh menguji efektivitas penegakan hukum lingkungan berdasarkan pemenuhan terhadap berbagai komponen, mulai dari deteksi, respon pemerintah terhadap pelanggaran hingga pada kemampuan pemerintah untuk membangun persepsi ${ }^{10}$.

Tulisan ini tidak untuk ditujukan berargumen terhadap persoalan efektivitas penegakan hukum administrasi untuk menghadapi perusakan lingkungan dengan pembuktian penggunaannya pada kasus-kasus konkrit. Selain telah banyak tulisan dan penelitian yang melakukan hal tersebut, Penulis berpendapat bahwa efektivitas dan efisiensinya penegakan hukum administrasi untuk menghentikan perusakan lingkungan akan sangat bervariatif tergantung pada berbagai dimensi yang menjadi konstekstual pelaksanaan penegakan hukum; baik infrastruktur kelembagaan, strategi dan kebijakan penegakan hukum, muatan pengaturan dan sebagainya. Tulisan ini secara khusus ditujukan untuk mencermati satu komponen utama yang jarang dibahas dalam penegakan hukum administrasi khususnya yang terkait dengan mencegah kegiatan eksploitasi sumber daya alam oleh usaha skala besar yang dapat menyebabkan kerusakan lingkungan.

Dari berbagai catatan kritis terhadap kebijakan perlindungan lingkungan, model command-and-control masih merupakan salah satu instrumen yang tetap dipertahankan. Upaya penguatan terhadap model tersebut dilakukan dengan cara meningkatkan akuntabilitas, maupun bagaimana proses penegakan hukum itu sendiri, maupun strateginya dilaksanakan. Penulis sepakat dengan berbagai pemikir yang akan dijabarkan dalam tulisan ini di bagian pembahasan, bahwa efektivitas penegakan hukum itu sendiri akan sangat berkaitan dengan bagaimana ukuran, bentuk, dan kontekstual penjatuhan sanksinya diperhatikan secara seksama. Tentunya juga sesuai dengan tujuan dan strategi penegakan hukum yang dibangun.

8 Anthony Ogus dan Carolyn Abbot. "Protection and Penalties." Symposium on Law and Economics of Environmental Policy, University College London (2001).

9 Faure dan Visser, loc.cit., hal.18.

10 Mas Achmad Santosa, Efektivitas Penegakan Hukum Administrasi Dalam Perlindungan dan Pengelolaan Lingkungan Hidup di Indonesia: Studi Kasus di Provinsi Jawa Tengah, (Depok: Universitas Indonesia, 2014). 
Untuk itu, tulisan ini akan mendeskripsikan berbagai bentuk penguatan terhadap model command-and-control melalui aspek sanksinya. Analisis yang disampaikan dalam tulisan ini diawali dengan memetakan berbagai tipologi pengaturan terkait penegakan hukum administratif yang ada dalam berbagai regulasi sumber daya alam. Beberapa argumen yang dikemukakan para proponen maupun kritik terhadap penegakan hukum administratif maupun terkait perbandingan antara hukum pidana dan administratif, apabila dibaca dalam perspektif yang berbeda juga sebenarnya dapat dibaca sebagai alat untuk melihat kembali batasan-batasan yang dimiliki oleh hukum administratif untuk dapat berjalan secara efektif. Batasan dan kemudian karakteristik dalam batasan tersebut, menjadi bahan awal untuk memetakan tipologi pengaturan penegakan hukum administrasi di Indonesia - khususnya yang terkait dengan perlindungan lingkungan hidup.

\section{Pengaturan Pelanggaran dan Sanksi Administratif Dalam Usaha Eksploitasi Sumber Daya Alam}

Sebelum menyimpulkan tipologinya, pada mulanya tulisan ini akan menjabarkan terlebih dahulu berbagai pengaturan pelanggaran dan sanksi administratif dalam perlindungan lingkungan hidup yang terkait usaha sektor sumber daya alam. Namun, sebagai catatan tambahan, penulis dengan sengaja akan tidak menyertakan Undang-Undang Nomor 32 Tahun 2009 tentang Perlindungan dan Pengelolaan Lingkungan Hidup ${ }^{11}$, untuk secara khusus menggarisbawahi kemampuan berbagai undang-undang sektoral mengatur upaya perlindungan lingkungan hidup secara administratif dalam eksploitasi sumber daya alam. Melalui norma-norma yang ada di dalamnya UU 32/2009 telah mengatur berbagai bentuk sanksi administratif. Pengaturan lebih lanjut mengenai bentuk pelanggaran maupun tata caranya diatur pun telah diatur dalam dalam aturan turunan, diantaranya Peraturan Pemerintah Nomor 27 Tahun 2012 tentang Izin Lingkungan dan Peraturan Menteri Lingkungan Hidup ${ }^{12}$ dan Peraturan Pemerintah Nomor 2 Tahun 2013 tentang Pedoman Penerapan Sanksi Administratif Di Bidang Perlindungan dan Pengelolaan Lingkungan Hidup ${ }^{13}$.

11 Selanjutnya disebut UU 32/2009.

12 Selanjutnya disebut PP 27/2012.

13 Selanjutnya disebut PermenLH 2/2013. 
Ketentuan pelanggaran administratif yang ada dalam rezim UU 32/2009 lebih dikhususkan untuk memaksakan ketaatan terhadap izin lingkungan. Kecuali terhadap perbuatan yang berdampak pada perusakan lingkungan hidup yang diatur dalam berbagai bentuk rumusan termasuk Pasal 100 UU 32/200914 dan Pasal 4 PermenLH 2/2013. Apabila dilihat dari rumusannya, pengaturan yang ada di dalam kedua pasal tersebut juga masih sangat umum. Tulisan ini dikaitkan dengan bagaimana pengaturan dalam usaha sektoral SDA menyediakan norma terhadap perlindungan terhadap lingkungan hidup. Tentu saja tiap usaha SDA memiliki karakteristik yang berbeda, dengan penggunaan ruang yang berbeda pula. Kriteria kerusakan lingkungan dalam PermenLH 2/2013 sepanjang pembacaan penulis belum melihat konteks tersebut. Istilah kerusakan lingkungan maupun baku mutu gangguan hampir tidak ada penjelasannya yang dapat dikaitkan dengan usaha eksploitasi sektor sumber daya alam. Dalam Pasal 4 PermenLH 2/2013 digunakan istilah kerusakan lingkungan, yang masih terlalu luas apabila harus digunakan dalam usaha seperti pertambangan atau perkebunan, misalnya. Berdasarkan hal tersebut, tulisan ini akan memfokuskan analisis terhadap ketentuan yang berlaku di sektor masing-masing, baik itu tambang, hutan maupun kebun yang dapat dikualifikasi sebagai bentuk upaya perlindungan lingkungan hidup.

Di dalam kerangka hukum ketiga sektor sumber daya alam, baik itu UndangUndang Nomor 41 Tahun 1999 tentang Kehutanan ${ }^{15}$, Undang-Undang Nomor 39 Tahun 2014 tentang Perkebunan ${ }^{16}$, dan Undang-Undang Nomor 4 Tahun 2009 tentang Pertambangan Mineral dan Batubara ${ }^{17}$, pengaturan mengenai sanksi administratif merupakan salah satu bentuk pertanggungjawaban yang secara khusus diatur. Akan tetapi, pengaturan mengenai penegakan hukum administratif

14 Disebutkan pada Pasal 100 ayat (1) UU 32/2009, bahwa “Setiap orang yang melanggar baku mutu air limbah, baku mutu emisi, atau baku mutu gangguan dipidana, dengan pidana penjara paling lama 3 (tiga) tahun dan denda paling banyak Rp3.000.000.000,00 (tiga miliar rupiah)". Namun pertanggungjawaban pidana tersebut diatur sebagai sanksi, apabila pelaku tidak mematuhi sanksi administratif. Hal ini diatur dalam ketentun ayat (2), yaitu, “Tindak pidana sebagaimana dimaksud pada ayat (1) hanya dapat dikenakan apabila sanksi administratif yang telah dijatuhkan tidak dipatuhi atau pelanggaran dilakukan lebih dari satu kali." Penebalan oleh penulis, sebagai penegasan bahwa keberlakuan Pasal 100 ayat (1) sebagai pidana adminsitratif (administrative penal).

15 Selanjutnya akan disebut sebagai UU 41/1999.

16 Selanjutnya akan disebut sebagai UU 39/2014.

17 Selanjutnya akan disebut sebagai UU 4/2009. 
di sektor sumber daya alam tersebar di berbagai tingkatan peraturan perundangundangan baik itu undang-undang hingga ke tingkatan peraturan menteri. Bagian awal tulisan ini akan mencermati bagaimana perlindungan lingkungan hidup menjadi salah satu bentuk kewajiban yang dikendalikan oleh pemerintah melalui sanksi administratif dalam berbagai sektor sumber daya alam ${ }^{18}$.

\subsection{Sektor Perkebunan}

Dalam Undang-Undang Nomor 39 Tahun 2014, pelanggaran yang diancam dengan sanksi administratif diatur cukup detil dalam 6 (enam) pasal $^{19}$. Terdapat 5 (lima) perbuatan yang diancam oleh sanksi administratif yang diatur di dalam UU 39/2014, yaitu, pelanggaran terhadap: 1) memindahkan hak atas tanah sehingga satuan luas usahanya kurang dari batas minimum dan tidak melakukan kegiatan usaha dalam jangka waktu tertentu, 2) tidak memfasilitasi pembangunan kebun masyarakat, 3) mengalihfungsikan lahan perkebunan dari kegiatan usaha perkebunan yang spesifik, 4) tidak membangun sarana prasarana, dan 5) usaha pengolahan yang tidak membangun kebun. Sebagian besar diantaranya diarahkan untuk memastikan bahwa kegiatan usaha perkebunan berjalan dengan optimal - termasuk diantaranya memberikan manfaat kepada masyarakat sekitar dengan memfasilitasi pembangunan kebun masyarakat. Sementara apabila dilihat dari bentuk sanksinya, pengaturan jenis-jenis sanksi yang disediakan dalam UU 39/2014 diatur sederhana, yaitu hanya meliputi denda, penghentian sementara dari kegiatan usaha, dan/atau pencabutan Izin Usaha Perkebunan. Tidak diatur misalnya bentuk sanksi seperti paksaan pemerintah lainnya yang dapat mendorong upaya kepatuhan.

Selain kewajiban-kewajiban yang diancam sanksi administratif apabila dilanggar, dalam UU 39/2014 diatur juga kewajiban yang berkaitan dengan

18 Sebagai catatan, tulisan ini memang tidak membaca secara menyeluruh aturan yang ada di dalam sektor kehutanan maupun perkebunan dan pertambangan, sehingga bukan tidak mungkin ada peraturan lain yang menjelaskan pelanggaran yang ada. Namun, pengaturan yang lebih sistematis jelas akan memudahkan aparat dalam melaksanakan penegakan hukum dan pelaku usaha untuk mematuhinya.

19 Diatur dalam Pasal 18 terhadap pelanggaran Pasal 15 dan Pasal 16, Pasal 60 terhadap pelanggaran Pasal 58, Pasal 64 terhadap pelanggaran Pasal 63 ayat (2), Pasal 65 terhadap pelanggaran Pasal 63 ayat (2), Pasal 70 terhadap pelanggaran Pasal 69, dan Pasal 75 terhadap pelanggaran Pasal 74 ayat (1). 
perlindungan lingkungan hidup, diantaranya sebagaimana yang diatur dalam Pasal 32 yaitu bahwa pelaku usaha pengolahan wajib mengikuti tatacara agar mencegah kerusakan lingkungan dan Pasal 67 untuk tidak membuka lahan dengan cara merusak fungsi dan memelihara kelestarian. Selain itu, jika dilihat dari tipologinya upaya perlindungan lingkungan hidup secara administratif dalam UU 39/2014 masih berfokus pada pemenuhan kondisi dampak kerusakan itu sendiri. Belum melihat tipologi perbuatan yang secara konkrit harus dilakukan sebagai prasyarat untuk mengklasifikasikan perbuatan sebagai perbuatan yang merusak lingkungan hidup. Sebagai misal, tidak diatur kewajiban tata cara pelaksanaan izin, yang berkaitan dengan perlindungan lingkungan hidup.

Pengaturan terkait kewajiban perlindungan lingkungan tersebut namun demikian tidak memiliki tipologi pengaturan yang sama. Kewajiban terkait perlindungan lingkungan tidak dirumuskan dalam bentuk larangan yang disertai sanksi, melainkan dalam bentuk kewajiban untuk melaksanakan suatu tata cara tertentu yang mengarahkan pada delegasi pengaturan pada aturan organisnya. Dalam Pasal 32 misalnya, meski diatur secara khusus perlindungan lingkungan dalam pembukaan atau pengelolaan lahan untuk keperluan budidaya justru tidak diatur sanksi yang dapat dibebankan apabila terjadi pelanggaran. Terhadap pengaturan kewajiban tersebut bahkan tidak diatur dengan bagaimana hukum administrasi harus merespon terhadap ketidak patuhan terhadap kewajibannya. UU 39/2014 tidak mengatur apakah ketidak patuhan untuk tidak merusak lingkungan dalam pembukaan lahan kemudian berdampak pada kewajiban tertentu bagi pelaku perusak lingkungan, misalnya pemulihan kerusakan atau pemberian insentif tertentu. Kecuali khusus terkait pembakaran lahan, UU 39/2014 dengan tegas mengancam dengan pasal pidana.

Selain yang diatur dalam UU 39/2014 sebagaimana telah diuraikan sebelumnya, larangan administratif yang disertai sanksi dapat ditemukan juga di dalam Peraturan Menteri Pertanian Nomor 98 Tahun 2013 tentang Pedoman Perizinan Usaha Perkebunan ${ }^{20}$. Permentan 98/2013 tersebut mengatur detil berbagai kewajiban yang kepatuhannya dipaksa melalui

20 Selanjutnya akan disebut sebagai Permentan 98/2013. 
ancaman sanksi adminsitratif. Khususnya kewajiban yang berusaha mendorong pembangunan usaha perkebunan secara optimal melalui fasilitasi terhadap kebun masyarakat dan pembangunan sarana prasarana. Berbeda dengan UU 39/2014, Permentan 98/2013 mengatur juga sanksi administratif terhadap kegiatan yang dianggap menyebabkan perusakan lingkungan (Pasal 52) atau tidak menjamin kelestariannya (Pasal 53). Dalam aturan ini, meski demikian, tidak disediakan penjelasan yang memadai terhadap apa yang disebut dengan tidak menjamin kelestarian atau menyebabkan kerusakan lingkungan. Apabila dilihat dari jenis sanksinya, ancamannya masih yang bersifat formal administratif seperti pencabutan izin usaha dan hak atas tanahnya. Bukan yang ditujukan untuk pemulihan dampak atau memberikan insentif untuk mencegah perbuatan.

Melihat pengaturan pelanggaran administratif dalam UU 39/2014 maupun Permentan 98/2013, ketentuan tersebut sangat mungkin untuk tidak terlaksana secara efektif. Pemberian sanksi terhadap perbuatan yang rumit untuk dibuktikan akan melemahkan efektivitas penegakan hukum administratif. Mengingat, penegakan hukum administratif tidak seperti penegakan hukum pidana yang melalui pembuktian materil di pengadilan, akan sangat membutuhkan kejelasan dalam pengaturan dan tata cara pelaksanaannya. Tanpa menafikan undang-undang yang secara khusus menangani perlindungan lingkungan hidup, seperti Undang-Undang Nomor 32 Tahun 2009 tentang Perlindungan dan Pengelolaan Lingkungan Hidup, tidak ada pengaturan pelarangan terhadap perbuatan usaha perkebunan, yang mendekati pada rujukan baku mutu lingkungan atau daya dukung dan tampung untuk kelestarian lingkungan, disediakan dalam kerangka UU $39 / 2014$.

Sementara itu, dari segi bentuk sanksinya, penegakan hukumadministratif terhadap usaha perkebunan cenderung lebih banyak menyebabkan beban kepada negara. Tidak dijelaskan bagaimana pertanggung jawaban pemegang izin terhadap kerusakan yang terjadi akibat pelanggaran administratif perusakan lingkungan. Mengingat di dalam kerangka hukum UU 32/2009 tidak terlalu jelas mengatur pemulihan kerusakan yang terjadi sebagai salah satu bentuk paksaan pemerintah. Di dalam Permentan 98/2013 dijelaskan 
sanksi terhadap Pasal 51 dan Pasal 53 adalah pencabutan izin dan pengusulan pencabutan hak atas tanah. Tata cara pemberian sanksi tidak diatur secara spesifik, begitu pula apabila perusakan lingkungan dihukum secara administratif dengan UU 32/2009, tidak diatur mekanisme koordinasi antara aparat pemerintah terkait dengan penjatuhan sanksi administratif tersebut. Hal ini tidak hanya menyebabkan ancaman sanksi tersebut lemah, tetapi juga tidak dapat dilaksanakan secara efektif.

\subsection{Sektor Pertambangan}

Undang-Undang Nomor 4 Tahun 2009 mengatur cukup banyak kewajiban administratif yang apabila dilanggar diancam dengan berbagai sanksi administratif, baik itu dalam bentuk peringatan tertulis, penghentian sementara kegiatan, maupun pencabutanizin. Pengaturannya tersebar diantara Pasal 40 hingga Pasal 150, termasuk terhadap pelanggaran atas kewajiban pemurnian, perlindungan lingkungan, hingga kewajiban untuk membayar royalti atau iuran atas eksploitasi barang tambang. Sebagai tambahan, meski tidak dinyatakan secara terang sebagai bentuk salah satu sanksi, UU 4/2009 juga mengatur penghentian sementara terhadap pelaksanaan kegiatan eksploitasi apabila lingkungan wilayah yang dibebani izin tersebut tidak dapat lagi menanggung beban kegiatan produksi di wilayahnya ${ }^{21}$.

Selain yang diatur dalam bentuk kewajiban yang disertai sanksi, sifat pengaturan dalam UU 4/2009 terhadap perlindungan lingkungan hidup, diatur secara beragam. Di dalam Pasal 166 UU 4/2009 misalnya, disebutkan bahwa segala persoalan terkait dampak lingkungan yang terjadi dalam pelaksanaan izin usaha terkait pertambangan (baik itu Izin Usaha Pertambangan, Izin Pertambangan Rakyat, maupun Izin Usaha Pertambangan Khusus) diselesaikan sesuai dengan ketentuan perundang-undangan yang berlaku. Namun, selain yang bersifat umum, berbagai pengaturan juga dilakukan secara khusus terhadap berbagai tahapan administrasi perizinan dalam ekploitasi sumber daya pertambangan. Dalam konteks yang khusus, dalam rangka untuk menjaga keseimbangan ekosistem dan lingkungan, Pemerintah dengan persetujuan Dewan juga dapat mengalokasikan

21 Lihat Pasal 113 ayat (1) UU 4/2009. 
Wilayah Pencadangan Negara. Pasal 18 disebutkan bahwa satu kriteria untuk menyatakan alokasi ruang untuk Wilayah Izin Usaha Pertambangan didasarkan pada daya dukung dan tampung lingkungan hidup. Kemudian, sebagai materi perizinan, undang-undang juga mengatur kewajiban klausa terkait persoalan lingkungan hidup, reklamasi dan pasca tambang sebagai muatan yang harus dalam keputusan izin usaha pertambangan.

Pengaturan kewajiban tersebut tidak hanya berada dalam tahap alokasi ruang maupun administrasi perizinan. Dalam pelaksanaan izinnya pun secara umum UU 4/2009 mengatur kewajiban bagi pemegang izin untuk mematuhi batas toleransi daya dukung lingkungan. Salah satunya kemudian diatur lebih detil dalam bentuk pengelolaan sisa tambang agar memenuhi standar baku mutu lingkungan sebelum di lepas ke media lingkungan. Kewajiban lainnya dalam usaha pertambangan yaitu, melakukan pemantauan lingkungan dan kegiatan reklamasi pasca tambang. Bahkan pemerintah sendiri diwajibkan untuk melakukan pembinaan dan dan pengamanan teknis terkait pengelolaan lingkungan hidup oleh pertambangan rakyat.

Melalui aturan turunannya pengaturan sanksi administratif tidak banyak berubah. Rumusan pengaturan yang sama dalam UU 4/2009, digunakan kembali dalam Peraturan Pemerintah Nomor 23 Tahun 2010 tentang Pelaksanaan Kegiatan Usaha Pertambangan Mineral dan Batubara22. Khusus mengenai reklamasi, Peraturan Menteri Energi dan Sumber Daya Mineral Nomor 7 Tahun 2014 tentang Pelaksanaan Reklamasi Dan Pascatambang Pada Kegiatan Usaha Pertambangan Mineral Dan Batubara ${ }^{23}$ mengatur lebih detil tentang berbagai kewajiban terkait reklamasi pasca tambang dan secara umum perlindungan lingkungan hidup di dalam areal izin usaha pertambangan yang apabila tidak dilaksanakan menjadi kriteria untuk penjatuhan sanksi administratif. Bahkan di dalam peraturan tersebut, prinsip perlindungan dan pengelolaan lingkungan hidup didefinisikan lebih rinci termasuk ${ }^{24}$ :

a. Perlindungan terhadap kualitas air permukaan;

b. Perlindungan dan pemulihan keanekaragaman hayati;

22 Selanjutnya disebut sebagai PP 23/2010.

23 Selanjutnya disebut sebagai PermenESDM 7/2014.

24 Lihat Pasal 2 ayat (3) PermenESDM 7/2014. 
c. Penjaminan stabilitas timbunan batuan;

d. Pemanfaatan lahan bekas tambang sesuai denga peruntukan; dan

e. Perlidungan terhadap kuantitas air tanah;

Prinsip tersebut kemudian harus diintegrasikan ke dalam dokumen rencana reklamasi pasca tambang, yang secara detil dijelaskan pada bagian lampiran peraturan.

Dilihat dari bentuk sanksinya, Pasal 151 ayat (2) dalam UU 4/2009, Pasal 110 PP 23/2010, maupun Pasal 67 dan Pasal 68 PermenESDM 7/2014 hanya mengatur bentuk-bentuk sanksi administratif seperti peringatan tertulis, penghentian sementara, dan pencabutan izin. Selain yang administratif formal tersebut, tidak diatur bentuk sanksi lain seperti moneter denda atau dalam bentuk paksaan pemerintah. Seperti halnya yang diatur di dalam aturan perkebunan, rujukan terhadap penyelenggaraan pertanggungjawaban secara administratif untuk perlindungan lingkungan di sektor pertambangan juga tidak diatur secara jelas - kecuali melalui mekanisme jaminan reklamasi pasca tambang yang diatur secara rinci. Terlepas dari hal tersebut, ketentuan dalam UU 4/2009 dan turunannya dirumuskan lebih jelas untuk mendefinisikan kerusakan lingkungan akibat usaha sektor pertambangan, ketimbang yang diatur dalam UU 39/2014.

\subsection{Sektor Kehutanan}

Di sektor kehutanan, pelanggaran administratif diatur dalam berbagai peraturan perundang-undangan. Pada tingkat undang-undang, pengaturan sanksi administrasi diatur singkat dalam Undang-Undang Nomor 41 Tahun 1999 tentang Kehutanan. Dalam Pasal 80 ayat (2) UU a quo, diatur secara umum bahwa setiap pemegang izin usaha pemanfaatan kawasan, izin usaha pemanfaatan jasa lingkungan, izin usaha pemanfaatan hasil hutan, atau izin pemungutan hasil hutan yangdiatur dalam undang undang ini, apabila melanggar ketentuan di luar ketentuan pidana sebagaimana diatur dalam Pasal 78 dikenakan sanksi administratif. Pada ayat (3) pasal a quo, dijelaskan bahwa pengaturan lebih lanjut akan diatur di dalam aturan turunan. Sementara itu pasal penjelasan mengatur bahwa sanksi administratif dimaksud dapat berupa denda, pencabutan izin, penghentian kegiatan, dan atau pengurangan areal. 
Pada Peraturan Pemerintah Nomor 45 Tahun 2004 junc to Peraturan Pemerintah Nomor 60 Tahun 2009 tentang Perlindungan Hutan ${ }^{25}$, pengaturan pelanggaran administratif diatur dengan lebih rinci. Beragam ketentuan mengenai upaya, kewajiban, dan tata cara terkait perlindungan hutan untuk membatasi kerusakan yang disebabkan oleh manusia, gangguan ternak, daya alam, maupun yang spesifik seperti kebakaran diatur. Akan tetapi, di dalam peraturan pemerintah sama sekali tidak disinggung sanksi administratif apabila norma-norma yang ada di dalam aturan tersebut dilanggar. Rumusan mengenai perbuatan yang dapat dikategorikan sebagai pelanggaran administratif baru dapat ditemukan dalam Peraturan Menteri Kehutanan Nomor: P.39/Menhut-II/ 2008 tentang Tata Cara Pengenaan Sanksi Administratif Terhadap Pemegang Izin Pemanfaatan Hutan ${ }^{26}$ mengatur berbagai sanksi administrasi, termasuk: 1) penghentian sementara pelayanan, 2) penghentian sementara kegiatan di lapangan, 3) denda administratif, 4) pengurangan jatah produksi, dan 5) pencabutan izin. Akan tetapi, ketentuan yang ada dalam peraturan menteri tersebut tidak menyebutkan sama sekali kerusakan lingkungan hidup sebagai dasar pengenaan sanksi. Aturan di dalam Permenhut P.39/2008 itu sendiri tidak merujuk pada perbuatan yang diwajibkan dalam PP 45/2004 jo. PP 60/2009 maupun UU 41/1999.

Sedikit berbeda dengan pengaturan yang terkait hasil hutan kayu, perlindungan terhadap sumber daya hayati, khususnya aturan administratifnya lebih banyak diatur di tingkat peraturan pemerintah. Dalam Peraturan Pemerintah Nomor 8 Tahun 1999 tentang Pemanfaatan Tumbuhn dan Satwa Liar $^{27}$ diatur setidaknya 19 pasal yang mengkualifikasi berbagai pelanggaran kewajiban untuk dikenakan sanksi administratif. Di antara Pasal 50 ayat (1) hingga Pasal 62, sanksi administratif dirumuskan terhadap perbuatan pemanfaatan tanpa izin hingga perdagangan satwa yang dilindungi - yang sebelumnya sudah diancam dengan sanksi pidana dalam UndangUndang Nomor 5 Tahun 1990 tentang Konservasi Sumber Daya Hayati dan Ekosistemnya $^{28}$.

25 Selanjutnya akan disebut sebagai PP 45/2004 jo. PP 60/2009.

26 Selanjutnya akan disebut sebagai Permenhut P.39/2008.

27 Selanjutnya akan disebut sebagai PP 8/1999.

28 Selanjutnya akan disebut sebagai UU 5/1990. 


\section{Tipologi Pengaturan Kepatuhan dan Sanksi Administratif}

\subsection{Model perumusan dan pengaturan kepatuhan}

Berdasarkan uraian yang telah dijabarkan pada bagian sebelumnya, dapat dilihat bahwa secara umum perlindungan lingkungan hidup cukup banyak diatur melalui instrumen hukum administrasi. Berbagai ketentuan di dalam undang-undang sektoral terkait sumber daya alam, di luar dari yang mengatur perlindungan lingkungan secara khusus seperti dalam UU 32/2009 diatur dengan berbagai bentuk. Dengan ketersediaan sanksi administratif di dalam aturan ketiga sektor kehutanan, perkebunan dan pertambangan, meskipun dengan berbagai kelemahan dalam rumusannya, secara umum model kepatuhan command-and-control masih dominan sebagai salah satu instrumen untuk memastikan perlindungan lingkungan hidup. Khususnya di sektor perkebunan dan pertambangan sanksi administratif terhadap pelanggaran kewajiban untuk melindungi lingkungan hidup dalam kegiatan usahanya diatur dengan tegas.

Berbagai kelemahan dalam rumusan pelanggaran administratif dalam perlindungan lingkungan hidup di sektor pertambangan, perkebunan maupun kehutanan, masih dapat ditemukan. Selain karena cenderung abstrak, rumusan yang ada juga sering terfragmentasi antara hirarki aturan hukumnya. Untuk sektor kehutanan, meski pelanggaran berbagai kewajiban perlindungan lingkungan secara detil disebutkan dalam PP 45/2004 jo. PP 60/2009, tidak ada sanksi administratif yang diatur terhadap kewajiban-kewajiban yang disebutkan dalam PP a quo. Aturan turunan dalam Permenhut P.39/2008 juga tidak mengatur sanksi administrasi yang berkaitan dengan perbuatan dalam PP 45/2004 secara menyeluruh. Karakteristik yang sama juga ditemukan di dalam aturan di sektor perkebunan. Dalam UU 39/2014 perlindungan lingkungan merupakan salah satu kewajiban pelaku usaha. Akan tetapi ketentuan administratif yang ada justru tidak menjelaskan bagaimana hukum administrasi harus merespon apabila terjadi pelanggaran terhadap kewajiban tersebut.

Selain catatan terhadap rumusan sanksinya, penting untuk diperhatikan bahwa dalam model command-and-control, perlindungan lingkungan cenderung didasarkan pada berbagai pengaturan kewajiban, standar, dan kriteria yang bersifat administratif ${ }^{29}$. Model yang demikian, menuntut peran pemerintah untuk

29 Arnold, C. Anthony, "Fourth Generation Environmental Law: Integrationist dan Multimodal", William and Mary Environmental Law and Policy Review, Vol 35-Issue 3 (2011). Menurut Arnold, model command-and-control yang disebutnya sebagai generasi pertama 
dapat mendefinisikan dan melakukan pengawasan secara efektif. Kemudian sanksi diberikan sebagai instrumen ex-post facto apabila pemerintah menemukan pelanggaran terhadap kewajiban administratifnya. Perihal pengawasan ini namun demikian tidak tergambarkan dengan norma yang lebih rinci dalam berbagai aturan untuk memastikan bahwa penegakan hukum administratif dapat berjalan efektif.

Meski aturan di sektor kehutanan memiliki kelemahan dalam mengatur sanksi administratif dalam perlindungan lingkungan akibat kegiatan usaha, akan tetapi UU 41/1999 merupakan salah satu aturan yang memperkenalkan upaya perlindungan lingkungan hidup di luar model command-and-control. Selain instrumen ex-post seperti sanksi, aturan di kehutanan maupun di pertambangan mengatur juga berbagai instrumen ex-ante yaitu dalam bentuk mekanisme insentif ekonomi maupun kontrak sosial ${ }^{30}$. Sebagai misal, di UU 41/1999 diperkenalkan aturan sejenis Pajak Pigouvian ${ }^{31}$ yang disebut dana jaminan kelestarian ${ }^{32}$. Seperti halnya sektor pertambangan yang melalui UU 4/2009 memperkenalkan partisipasi publik dalam merancang pertambangan rakyat.

muncul dari: "1) early environmental protection efforts that sought to enforce common-law tort remedies and property rights against environmental harm; 2) government reservation and management of lands and natural resources; 3) early but limited federal statutes; and 4) a strong grassroots social and political movement of environmentalism."

30 Menurut A.C. Pigou permasalahan eksternalitas negatif dapat diselesaikan dengan membebankan pajak pada setiap unit produksi, sehingga nilainya setara dengan biaya eksternal marjinal. Dengan membebankan pajak tersebut, maka biaya untuk memproduksi suatu barang akan lebih mampu merefleksikan biaya sosialnya. Akibat dari biaya yang mahal tersebut, perusahaan akan terdorong untuk memproduksi lebih sedikit, sementara biaya sosial tersebut akan ditanggung oleh produsen dan konsumen. Konsekuensi lebih lanjut, masyarakat umum akan mendapatkan 'ganti rugi' terhadap biaya eksternalitas yang terjadi. Mekanisme fiskal yang demikian kemudian dikenal dengan istilah Pigouvian Tax, mengikuti nama pencetusnya. Lihat Steven C. Hackett, Environmental and Natural Resources Economics: Theory Policy and the Sustainable Society (3 ${ }^{\text {rd }}$ Edition), (M.Sharpe, New York: 2006), hal. 79-80.

31 Michael G. Faure, "Instruments for environmental governance: what works?", (artikel dipaparkan pada Annual Colloquium of the Academy for Environmental Law of the IUCN di Wuhan 1-5 November 2009), hal. 11.

32 Lihat penjelasan Pasal 35 ayat (1) UU 41/1999, disebutkan bahwa, “Dana jaminan kinerja adalah dana milik pemegang izin usaha peman-faatan hutan, sebagai jaminan atas pelaksanaan izin usahanya, yang dapat dicairkan kembali oleh pemegang izin apabila kegiatan usaha-nya dinilai memenuhi ketentuan usaha pemanfaatan hutan secara lestari." Kelestarian dalam norma tersebut disebut sebagai tanda bahwa pemerintah telah melakukan upaya yang memadai, termasuk membiayai pengusahaan hutannya untuk menjamin tercapainya kelestarian hutan yang diusahakan. Apabila kinerja pelaku usaha tersebut tidak baik dan kelestarian tidak tercapai, maka hal tersebut akan menjadi biaya eksternalitas. Untuk menghilangkan beban eksternalitas kepada publik, maka UU 41/1999 membebankan biaya tersebut kepada perusahaan sebagai bentuk jaminan. 
Pergeseran atau mungkin lebih tepat lagi perkembangan dari model commandand-control menuju berbagai fase lainnya termasuk mekanisme insentif ekonomi atau pasar telah banyak dibahas ${ }^{33}$. Penggunaan insentif ekonomi seperti dana jaminan yang diatur di sektor kehutanan dan pertambangan merupakan salah satu bentuk trend yang terjadi dalam perlindungan lingkungan hidup. Melalui insentif tersebut, pelaku usaha difasilitasi untuk memiliki otonomi dan fleksibilitas dalam menjalankan usahanya namun tetap didasarkan pada pendekatan risiko yang diawasi oleh pasar. Ilustrasi lainnya penggunaan mekanisme pasar ini misalnya dengan instrumen sertifikasi seperti Sertifikasi Pengelolaan Hutan Produksi Lestari di sektor kehutanan dan Indonesia Sustainable Palm Oil (ISPO) untuk sektor perkebunan kelapa sawit.

\begin{tabular}{|l|l|l|l|}
\hline \multicolumn{1}{|c|}{ Kriteria } & \multicolumn{1}{c|}{ Perkebunan } & \multicolumn{1}{c|}{ Kehutanan } & \multicolumn{1}{c|}{ Pertambangan } \\
\hline Rumusan & $\begin{array}{l}\text { Pengaturan } \\
\text { kewajiban. } \\
\text { Bersifat } \text { ex } \\
\text { post melalui } \\
\text { command and } \\
\text { control }\end{array}$ & $\begin{array}{l}\text { Pengaturan kewajiban } \\
\text { dan insentif/ jaminan. } \\
\text { Bersifat } \text { ex ante } \\
\text { maupun } \text { ex post } \\
\text { melalui command and } \\
\text { control }\end{array}$ & $\begin{array}{l}\text { Pengaturan } \\
\text { kewajiban dan } \\
\text { insentif/ jaminan. } \\
\text { Bersifat } \text { ex ante dan } \\
\text { ex post tidak hanya } \\
\text { command and control }\end{array}$ \\
\hline $\begin{array}{l}\text { Kumulasi } \\
\text { eksternal }\end{array}$ & $\begin{array}{l}\text { kidak ada } \\
\text { eksternal, } \\
\text { kecuali terkait } \\
\text { kebakaran }\end{array}$ & $\begin{array}{l}\text { Khusus terkait } \\
\text { sumber daya hayati, } \\
\text { ditemukan kumulasi } \\
\text { eksternal dengan } \\
\text { perlindungan akan } \\
\text { tetapi tidak dijelaskan } \\
\text { dalam aturan turunan }\end{array}$ & $\begin{array}{l}\text { Tidak ada kumulasi } \\
\text { eksternal }\end{array}$ \\
\hline $\begin{array}{l}\text { Sanksi } \\
\text { moneter }\end{array}$ & Diatur & Tidak diatur & Tidak diatur \\
\hline $\begin{array}{l}\text { Sanksi } \\
\text { komplementer } \\
\text { pemulihan }\end{array}$ & Tidak diatur & $\begin{array}{l}\text { Diatur sebagai ganti } \\
\text { rugi }\end{array}$ & Tidak diatur \\
\hline
\end{tabular}

Tabel 1. Tipologi pengaturan kepatuhan administratif dalam perlindungan lingkungan

33 Gunningham, loc.cit., hal. 7-20. Dalam makalah tersebut Gunningham menjelaskan berbagai bentuk mekanisme pasar, seperti insentif ekonomi, sertifikasi, dan pajak yang digunakan untuk mendorong kepatuhan pelaku usaha dalam perlindungan lingkungan. Gunningham kemudian menyimpulkan bahwa model ancaman tidak lagi dapat diandalkan hanya sebagai satu-satunya instrumen. 
Perkembangan pengaturan mengenai perlindungan lingkungan hidup tersebut, tidak serta merta menghilangkan sama sekali model command-and-control. Pertanggungjawaban baik pidana maupun administratif tetap merupakan salah satu instrumen hukum yang memiliki efektivitasnya sendiri untuk mencegah atau memulihkan kerusakan lingkungan hidup akibat kegiatan usaha ekstraktif. Instrumen ekonomi sendiri memiliki kelemahan fatal, salah satunya karena memberikan ruang moral hazard, dengan cara mengakali tujuan pencegahan kerusakan dengan cara membayar terhadap kerusakan atau polusi yang terjadi ${ }^{34}$. Sehingga ketimbang menyatakan pergeseran fase, upaya perlindungan lingkungan lebih sesuai disebut mengalami perkembangan, yang mana model dan instrumen baru saling melengkapi dan terintegrasi atau istilah Arnold, yaitu multimodal ${ }^{35}$.

Beberapa upaya untuk memperkuat model command-and-control berkembang dengan upaya untuk memperkuat efek yang diharapkan dihasilkan dalam perlindungan lingkungan. Kritik terhadap command-and-control khususnya yang terkait sanksi administratif bisa jadi tidak relevan lagi, mengingat beragam perkembangan dalam sanksi administratif, di Indonesia misalnya tidak terbatas pada sanksi moneter semata ${ }^{36}$. Penguatan terhadap efek pengancam (detterence effect) dilakukan dengan penguatan sanksi khususnya melalui penggabungan dengan hukum pidana ${ }^{37}$. Sementara itu, beberapa pakar juga mendorong adaptasi instrumen ekonomi dengan hukum administrasi dengan merancang disinsentif terhadap kerusakan lingkungan melalui penambahan bentuk sanksi lain, seperti sanksi pemulihan. Sehingga sanksi administratif tidak lagi hanya berkutat pada tujuan untuk menghentikan perbuatan pelaku usaha. Pada bagian berikutnya dalam tulisan ini akan dibahas bagaimana peluang dan tantangan dalam penguatan model command-and-control dalam hal perlindungan lingkungan hidup.

\subsection{Kumulasi eksternal}

Penggabungan atau penguatan sanksi administratif dengan pendampingan sanksi pidana merupakan trend yang banyak berkembang dalam perlindungan

34 Faure, 2009, ibid.

35 Arnold, op.cit., hal. 880.

36 Faure dan Visser, hal. 15.

37 Thomas Blondiau, Carole M. Billiet, dan Sandra Rousseau. "Comparison of criminal and administrative penalties for environmental offenses." European Journal of Law and Economics 39.1 (2015), hal. 11-35. 
lingkungan hidup ${ }^{38}$. Terutama karena sanksi administrasi dipandang sangat lemah untuk menjadi insentif untuk mencegah pelanggaran hukum, mengingat sanksi pidana hanya ditujukan untuk menghentikan perbuatan pelanggaran itu sendiri ${ }^{39}$. Dijelaskan oleh beberapa pemikir hukum administrasi bahwa sementara sanksi administrasi ditujukan untuk kepada perbuatan pelanggarannya, sanksi pidana ditujukan kepada si pelanggar. Sanksi administrasi khususnya ditujukan agar perbuatan pelanggaran itu dihentikan. Hadjon et.al., kemudian juga menjelaskan karakteristik hukum administratif yang khusus ada pada sanksi berupa paksaan pemerintah (bestuurdwang). Sanksi administratif yang lainnya, seperti denda, lebih banyak ditujukan sebagai penambah nestapa; merupakan sanksi yang tidak langsung dalam konteks hukum administrasi (weken meer indirect)- sehingga lebih sesuai dengan karakteristik sanksi pidana. Bestuurdwang merupakan tindakan langsung administrasi negara (feitelijke handeling) guna mengkahiri suatu keadaan yang dilarang oleh hukum administrasi.

Ada dua bentuk yang mana sanksi administratif dan sanksi pidana berkumulasi sehingga menghasilkan perbuatan yang dapat dipertanggungjawabkan secara pidana maupun administratif (mala administratione prohibita) ${ }^{40}$. Dalam literatur hukum di Indonesia, penggabungan ini dikenal dengan istilah kumulasi eksternal ${ }^{41}$. Bentuk pertama yaitu ketika sanksi pidana bergantung sepenuhnya pada aturan administratif $^{42}$. Dalam bentuk ini, pertanggungjawaban pidana dijatuhkan pada pelanggaran ketentuan-ketentuan yang diwajibkan secara administratif. Ketiadaan dokumen izin misalnya atau surat keterangan yang dijadikan dasar sebagai penjatuhan sanksi pidana. Untuk bentuk yang kedua, sanksi pidana

38 Selain Faure dan Visser (2003) yang berulang kali disebutkan, simpulan yang sama juga disampaikan oleh Svastikova dalam tulisannya bersama Faure, "Criminal or Administrative Law to Protect the Environment? Evidence from Western Europe." Journal of environmental law 24.2 (2012).

39 Hadjon, et.al., op.cit.

40 Dalam kaitannya dengan hukum administratif, bentuk lainnya yaitu, ketika sanksi pidana benar-benar independen terhadap ketentuan administratif. Sanksi pidana yang demikian didasarkan pada rumusan pelanggaran yang bersifat materil. Kelemahan dari tindak pidana yang demikian menurut Gunther Heine yaitu pendefinisian pelanggaran secara materil, seringkali ukurannya sulit untuk ditentukan. Contohnya, hingga saat ini ukuran kerusakan lingkungan masih menjadi persoalan, lihat dalam Gunter Heine, "Elaboration of Norms and the Protection of the Environment." Duke Envtl. L. E Pol'y F. 2 (1992), hal. 106.

$41 \quad$ Ibid.

42 Ibid. 
dapat dijatuhkan meski tidak bergantung secara mutlak terhadap pelanggaran administratif $^{43}$. Misalnya, ketika pidana dapat dijatuhkan baik terhadap pelanggaran berulang maupun apabila terjadi terjadi pelanggaran administratif ${ }^{44}$.

Beberapa pemikir hukum lingkungan masih belum sepakat sepenuhnya dengan ide ini. Kumulasi eksternal ini menurut Faure misalnya harus dicegah untuk menyebabkan ketergantungan hukum pidana terhadap aturan administratif ${ }^{45}$. Faure mengkhawatirkan ketergantungan ini menyebabkan pertanggungjawaban berjalan terlambat terhadap bahaya lingkungan yang mudah terlihat. Sementara itu Heine kemudian menekankan bahwa penggunaan dua deterrence effect belum tentu saling menguatkan ${ }^{46}$. Kepatuhan terhadap hukum dapat secara signifikan turun apabila penggunaan sanksi administratif khususnya yang merupakan denda seringkali jauh lebih ringan ketimbang sanksi pidana, sementara hukum pidana yang ada tidak serta merta meningkatkan risiko deteksi bagi pelanggar hukum. Selain itu, Heine juga memperkirakan persoalan konflik kewenangan antara lembaga penegak hukum ${ }^{47}$.

Catatan penting terhadap kumulasi, hemat penulis harus dilakukan dengan memperhatikan posisi hukum pidana ketika berkesesuaian dengan sanksi administratif. Harus dibedakan bahwa dalam relasi tersebut ada bentuk yang membuat sanksi pidana diposisikan di bawah sanksi administratif, yaitu ketika pertanggungjawaban pidana hanya bisa diberikan ketika terjadi ketidakpatuhan terhadap sanksi administratif. Bentuk berikutnya terjadi ketika satu perbuatan atau pelanggaran dapat dikualifikasi dengan baik sanksi pidana maupun administratif tanpa menjelaskan primasi dari salah satu sanksi.

43 Ibid.

44 Ibid.

45 Michael G. Faure, D. Bernard, Y. Cartuyvels, Chr Guillain, D. Scalia, dan M. van de Kerchove. "Responsabilité pénale environnementale en Europe: quo vadis?." Fondements et objectifs des incriminations et des peines en droit européen et international (2013), hal. 332. Disebutkan oleh Faure, "La dépendance administrative a comme conséquence que la pollution en soi n'est pas directement punie par une sanction pénale, mais indirectement lorsque la pollution constitue également une violation d'obligations administratives, de sorte que l'intéressé a agi contrairement à l'autorisation délivrée en vertu de la loi. Du moment que les obligations administratives sont respectées (ou que les obligations administratives n'ont pas été déterminées), le droit pénal ne peut pas accorder sa protection à l'environnement."

46 Heine, loc.cit., hal. 112-114.

47 Ibid, hal. 100. 
Terlepas dari catatan tersebut, diakui oleh hampir seluruhnya bahwa pengaturan ganda terhadap perbuatan untuk dikenakan sanksi administrasi dan pidana secara kumulatif berpeluang memberikan kekuatan politik bagi pemerintah untuk mendorong kepatuhan pelaku usaha dalam melaksanakan kewajiban yang terkait dengan perlindungan lingkungan hidup. Selain itu perlu dipertimbangkan juga bahwa sanksi administratif tidak dapat menjangkau beneficial owner yang mendapatkan keuntungan dari pelanggaran hukum. Tipologi pengaturan tersebut sudah diperkenalkan dalam konteks perlindungan lingkungan atau sumber daya alam, bukan hal yang baru. Melalui PP 8/1999 misalnya, sebagaimana dibahas sebelumnya sudah diatur bagaimana sanksi administratif dapat dikenakan berlapis dengan sanksi pidana.

Kumulasi eksternal atau pengenanaan hukum pidana dan administratif secara bersamaan atas satu pelanggaran hukum dapat ditemukan dalam sektor kehutanan. Pasal 50 ayat (2) UU 41/1999 mengatur ketentuan pidana mengenai perusakan hutan oleh pemegang izin, yang kemudian dilanjutkan dengan ketentuan berikutnya yang menjelaskan bahwa pemidanaan tersebut juga dapat diikuti dengan sanksi administratif. Namun, norma yang diatur dalam UU 41/1999 secara abstrak tersebut, tidak diatur lebih detil dalam aturan turunannya. Baik dalam PP 45/2004 maupun Permenhut P.39/2008. Ketentuan yang sejenis tidak ditemukan baik dalam sektor pertambangan maupun perkebunan, kecuali yang terkait dengan kebakaran lahan. Sebagai tambahan, dari keseluruhan kumulasi tersebut, tidak ada satupun yang menempatkan sanksi pidana di bawah posisi aturan administratif. Model ketergantung terhadap pelanggaran administratif yang demikian, hanya ditemukan dalam UU 32/2009.

\subsection{Sanksi moneter denda dan moneter pemulihan}

Sanksi denda dalam hukum administrasi merupakan bentuk untuk menghukum masyarakat yang tidak mematuhi kewajibannya. Meski tidak diarahkan untuk menghentikan perbuatan semata, seperti layaknya sifat sanksi administrasi pada umumnya, denda sebagai sanksi adminsitratif dianggap lebih efektif sebagai disinsentif untuk membangun perilaku dalam perlindungan lingkungan hidup ${ }^{48}$. Kekhususan sanksi denda dalam hukum administrasi terutama

48 Svastikova, K., op.cit., 2010, hal. 1 dan hal. 17. 
karena dapat langsung dibebankan kepada pelanggar hukum tanpa proses ajudikasi yang berlarut-larut - khususnya terhadap pelanggaran administratif yang ringan ${ }^{49}$.

Tentu saja untuk dapat menjadi insentif yang sangat kuat dalam kepatuhan perlindungan lingkungan hidup, diperlukan pengaturan yang lebih khusus lagi, tidak hanya dari segi jumlah yang tepat, termasuk juga mekanisme pengawasan yang akuntabel. Dengan menyitir risetnya Rousseau pada tahun 2007, Faure juga lebih lanjut menekankan pentingnya memastikan akuntabilitas pengenaan sanksi denda tersebut dengan menjelaskan perilaku pelaku usaha yang didasarkan pada persepsinya terhadap penjatuhan sanksi ${ }^{50}$. Riset tersebut menjelaskan bahwa pelaku usaha yang telah membayar sanksi denda pada 2 (dua) tahun periode sebelumnya, cenderung akan jauh lebih banyak melakukan pelanggaran hukum pada periode berikutnya ketimbang yang tidak dikenakan sanksi denda pada periode sebelumnya.

Terlepas dampak menyimpang dari denda tersebut, denda dalam ketiga sektor tersebut tidak banyak digunakan sebagai bentuk sanksi administratif. Terhadap regulasi yang dibaca untuk tulisan ini, denda hanya digunakan sebagai sanksi administratif di sektor kehutanan melalui Permenhut P.39/2008. Tidak diketahui dengan jelas apakah dampak penggunaan denda tersebut positif atau negatif jika dikaitkan dengan Permenhut P.39/2008.

Seperti halnya denda, ganti rugi atau paksaan pemerintah untuk pemulihan juga merupakan sanksi yang sifatnya menghukum - tidak hanya menghentikan perbuatan pelaku seperti pencabutan izin atau penutupan lubang limbah misalnya. Dengan paksaan untuk pemulihan, tujuan utamanya untuk mengembalikan seperti keadaan semua sebelum terjadinya kerusakan lingkungan.

Faure dan Visser sendiri mengkritik perihal ganti rugi yang secara inheren tidak masuk akal. Inefisiensi akan tetap terhitung ketika kerusakan lingkungan hidup terjadi, mengingat tidak jarang kerusakan lingkungan yang terjadi tidak

49 Ibid. Dalam tulisannya Svastikova menggunakan pemodelan berargumen bahwa keuntungan dari turunan emisi dan penegakan hukum akan melebihi biaya pencegahan. Sehingga dapat dibaca dari perspektif perusahaan, insentif akan lebih baik jika perusahaan menyediakan biaya untuk melakukan pencegahan kerusakan.

Faure, 2009, op.cit., hal. 21. 
mungkin pulih seperti sediakala ${ }^{51}$. Akan tetapi penggunaan paksaan pemerintah untuk pemulihan, khususnya di dalam perlindungan lingkungan hidup sangat beriringan dengan konsep pencemar membayar yang kemudian diperluas termasuk kepada kerusakan lingkungan. Dengan sanksi yang demikian, pelaku usaha juga dipaksa untuk menginternalisasi biaya-biaya yang digunakan untuk mencegah terjadinya kerusakan.

Dilihat dari ketiga sektor yang ada, tidak ada satupun sektor yang mengatur pemulihan kerusakan sebagai bentuk sanksi administrasi. Di dalam UU 41/1999 memang menyebutkan pemulihan terhadap kerusakan hutan, akan tetapi pengaturan tersebut diletakkan sebagai bentuk ganti rugi terhadap tindak pidana. Sehingga pertanggungjawaban kerugiannya pun, hanya dapat diberlakukan dalam kerangka penegakan hukum pidana. Dengan pengaturan sanksi moneter dan non moneter yang demikian dapat dikatakan bahwa penegakan hukum administrasi yang dirumuskan bertendensi lebih banyak membebani pemerintah ketimbang pelaku pelanggaran.

\section{Simpulan}

Tulisan ini secara umum memperlihatkan bahwa perlindungan lingkungan hidup melalui instrumen hukum administrasi sudah menjadi bagian dari kelaziman berjalannya sistem hukum di Indonesia. Berbagai ketentuan di dalam undang-undang sektoral terkait sumber daya alam, di luar dari yang mengatur perlindungan lingkungan secara khusus seperti dalam UU 32/2009 diatur dengan berbagai bentuk. Bahkan tidak hanya sebagai instrumen ex post facto, tetapi juga ex ante yaitu dalam bentuk instrumen pasar maupun kontrak sosial.

Catatan pengaturan yang ada dalam perlindungan lingkungan justru berkaitan dengan penegakan hukum administrasi itu sendiri. Meski hukum administrasi khusus yang ada di masing-masing sektor sumber daya alam telah mengaturnya, pengaturan mengenai jenis sanksi dan kewajiban apa yang dapat dikenakan sanksi belum diatur secara memadai. Dari ketiga sektor sumber daya alam, baik kehutanan, perkebunan, maupun pertambangan yang dicermati dalam

51 Faure, 2003, op.cit., hal. 2. Dalam tulisan tersebut Faure dan Visser memang sedang membandingkan antara sanksi pidana dengan ganti rugi perdata. Faure misalnya mencontohkan bagaimana ganti rugi tidak mungkin menggantikan hilangnya tangan. 
tulisan ini, keseluruhannya tidak memiliki kejelasan runtutan aturan terhadap penegakan administrasi baik ditingkat norma, prosedur, maupun kriterianya.

Tipologi yang ada memperlihatkan pengaturan yang terpecah dan tidak terhubung satu sama lain antar regulasi, bahkan yang berada dalam satu sektor. Sebagai misal, kewajiban perlindungan lingkungan yang ada di dalam PP 45/2004 jo. PP 60/2009 justru tidak diatur sanksi administrasinya - termasuk ketika dicermati aturan turunannya. Ketidak jelasan konseptual pelanggaran administrasi yang ada di dalam aturan terlihat dari lemahnya rumusan aturan dalam mendefinisikan kerusakan lingkungan yang dapat dibebankan sanksi administrasi. Berbagai aturan menjelaskan definisi kerusakan lingkungan dalam bentuk yang sangat abstrak tanpa penjelasan yang memadai. Definisi kerusakan lingkungan tidak pernah dikontekstualkan berdasarkan karakteristik pengelolaan sumber daya alam masing-masing sektor. Tidak ada penjelasan normatif terhadap definisi kerusakan lingkungan di sektor pertambangan atau pun perkebunan.

Kelemahan lainnya juga terlihat dari masih lemahnya upaya penguatan model command-and-control dalam perlindungan lingkungan hidup untuk usaha sektor sumber daya alam. Kumulasi dengan pemidanaan hampir tidak dapat ditemukan, sebagai salah satu strategi untuk meningkatkan efek pengancam (detterence effect). Meski UU 41/1999 menyebutkan pelanggaran pidana tersebut dapat dikenakan administrasi, tidak ada pengaturan yang menjabarkan lebih jelas tatacara atau bahkan sanksi apa yang berlaku pada masing-masing perbuatan pidana tersebut. Penggunaan sanksi komplementer secara spesifik bertujuan memulihkan kerugian lingkungan hidup yang terjadi akibat ekstraksi yang berlebihan juga tidak dapat ditemukan.

Analisis terhadap regulasi yang ada dalam tulisan ini menjelaskan secara umum bahwa upaya untuk memastikan penegakan hukum dalam perlindungan lingkungan hidup masih merupakan jalan yang panjang. Untuk membuat model command-and-control lebih memadai pembuat kebijakan perlu melakukan harmonisasi regulasi untuk penguatan penegakan hukum administrasi, tidak hanya rumusan sanksinya, termasuk juga tata cara dan strategi penegakan hukumnya itu sendiri. 


\section{DAFTAR PUSTAKA}

\section{$\underline{\text { Buku }}$}

Faure, Michael G. dan Phillipsen, N. Contribution to conclusions and recommendations on environmental crime: System of Sanctions. European Union Action to Fight Environmental Crime, 2016.

Faure, Michael G. dan Zhang, Hao. Environmental Criminal Law: a Critical Analysis. Environmental Law Institute: Washington DC, USA, 2011.

Hackett, C. Steven. Environmental and Natural Resources Economics: Theory Policy and the Sustainable Society (3rd Edition), M.Sharpe: New York, 2011.

Hadjon, M. Philipus, Martosoewignjo, Sri Soematri, Basah, Sjahcran, Manan, Bagir, Marzuki, H.M., Laica, ten Berge, J.B.J.M., van Buuren, P.J.J., dan Stroink, F.A.M. Pengantar Hukum Administrasi Indonesia. Gajah Mada University Press: Yogyakarta, Indonesia, 2015.

Hirakuri, Sofia R. Can Law Save the Forest? Lessons from Finland and Brazil. Center for International Forestry Research: Bogor, Indonesia, 2003.

Santosa, Mas A. Efektivitas Penegakan Hukum Administrasi Dalam Perlindungan dan Pengelolaan Lingkungan Hidup di Indonesia: Studi Kasus di Provinsi Jawa Tengah. Universitas Indonesia: Depok, 2014.

Svastikova, K. Economic Criteria for Criminalization: Optimizing Enforcement in Case of Environmental Violations. Intersentia: Cambridge, 2012.

Jurnal dan Makalah

Arnold, C. Anthony. "Fourth Generation Environmental Law: Integrationist and Multimodal". William E Mary Environmental Policy Review Volume 45 Issue 3 (2011).

Blondiau, T., Billiet, Carole M. dan Rousseau, S. "Comparison of criminal and administrative penalties for environmental offenses." European Journal of Law and Economics 39.1 (2015). Diakses 2 Januari 2017 melalui alamat https://lirias. kuleuven.be/bitstream/123456789/470345/2/15_TB-CMB-SR_crim-adminmatch-EJLE-final.pdf.

Cole, Daniel H. dan Grossman, Peter Z. 1999. “When Is Command-and-Control Efficient? Institutions, Technology, and the Comparative Efciency of Alternative Regulatory Regimes for Environmental Protection". Maurer Faculty Paper 590. Dapat diunduh melalui http:// www.repository.law.indiana.edu/facpub/590. 
Faure, Michael G. "Instruments for environmental governance: what works?" (Artikel dipaparkan pada Annual Colloquium of the Academy for Environmental Law of the IUCN di Wuhan 1-5 November 2009).

Faure, Michael G. "Responsabilité pénale environnementale en Europe : quo vadis?", dalam Fondements et objectifs des incriminations et des peines en droit européen et en droit international, Anthémis, 2013. Diakses penulis tanggal 14 Februari 2017 pada alamat http://www.tradevenvironment. eu/index.php? mact $=$ papers, cntnt01,get_papers_in_cat,0\&cntnt01cat

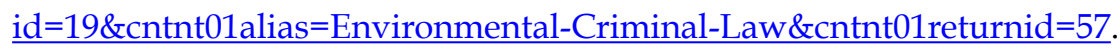

Faure, Michael G., dan Visser, Marjolein. "Law and Economics of Environmental Crime: a Survey", (2003).

Faure, Michael G., Koopmans, I., dan Oudijk, J. "Imposing criminal liability on government officials under environmental law: a legal and economic analysis". Loyola of Los Angeles International and Comparative Law Journal (1996).

Gunningham, Neil. "Beyond Compliance: Next Generation Environmental Regulation" (Tulisan dipresentasikan pada seminar, 'Enforcement and Compliance Conference' diselenggarakan oleh Australian Institute of Criminology bekerjasama dengan the Regulatory Institutions Network, RSSS, Australian National University dan Division of Business and Enterprise. University of South Australia: Melbourne. September 2-3, 2002).

Ogus, A., dan Abott, C. "Pollution and penalties" (Tulisan dipresentasikan pada Simposium berjudul 'Law and Economics of Environmental Policy'. University College, London, pada bulan September 2001).

Stewart, Richard B. "Regulation, innovation, and administrative law: A conceptual framework." California Law Review 69.5 (1981). Dapat diunduh melalui: http:/ / scholarship.law.berkeley.edu/californialawreview/vol69/iss5/, diakses 21 Desember 2016.

Svastikova, K. "Complementary use of administrative and criminal fines in enforcing environmental regulations" (2010). Diakses tanggal 3 Januari 2017 melalui alamat: https://editorialexpress.com/cgi-bin/conference/download.cgi?db $\underline{\text { name }=\text { ALEA2010\&paper } \_i d=115}$

Instrumen Hukum Nasional

Indonesia. Undang-Undang tentang Kehutanan. UU No. 41 Tahun 1999. LN Tahun 1999 No.167. TLN No. 3888. 
Indonesia. Undang-Undang tentang Konservasi Sumber Daya Alam Hayati dan Ekosistemnya. UU No. 5 Tahun 1990. LN Tahun 1990 No. 49.

Indonesia. Undang-Undang tentang Perlindungan dan Pengelolaan Lingkungan Hidup. UU No. 32 Tahun 2009. LN Tahun 2009 No. 140. TLN No. 5059.

Indonesia. Undang-Undang Tentang Perkebunan. UU No. 39 Tahun 2014. LN Tahun 2014 No. 308. TLN No. 5613.

Indonesia. Undang-Undang tentang Pertambangan Mineral dan Batubara. UU No. 4 Tahun 2009. LN Tahun 2009 No. 4. TLN No. 4959.

Indonesia. Peraturan Pemerintah tentang Izin Lingkungan. PP No. 27 Tahun 2012. LN Tahun 2012 No. 48. TLN No. 5285.

Indonesia. Peraturan Pemerintah tentang Pelaksanaan Kegiatan Usaha Pertambangan Mineral dan Batubara. PP No. 23 Tahun 2010. LN Tahun 2010 No. 29. No. TLN 5111. Indonesia. Peraturan Pemerintah tentang Pemanfaatan Tumbuhan dan Satwa Liar. PP No. 8 Tahun 1999. LN Tahun 1999

Indonesia. Peraturan Pemerintah tentang Perlindungan Hutan. PP No. 45 Tahun 2004 jo. PP No. 60 Tahun 2009. LN Tahun 2009 No. 137. TLN No. 5056,

Indonesia. Peraturan Menteri Energi dan Sumber Daya Mineral tentang Pelaksanaan Reklamasi dan Pascatambang Pada Kegiatan Usaha Pertambangn Mineral dan Batubara. BN Tahun 2014 No. 274.

Indonesia. Peraturan Menteri Energi dan Sumber Daya Mineral tentang Pelaksanaan Reklamasi Pascatambang Pada Kegiatan Usaha Pertambangan Mineral dan Batubara. PermenESDM No. 7 Tahun 2014. BN Tahun 2014 No. 274.

Indonesia. Peraturan Menteri Kehutanan tentang Tata Cara Pengenaan Sanksi Administratif Terhadap Pemegang Izin Pemanfaatan Hutan. Permenhut P.39/2008. BN Tahun 2008 No. 14.

Indonesia. Peraturan Menteri Lingkungan Hidup tentang Pedoman Penerapan Sanksi Administratif Di Bidang Perlindungan Dan Pengelolan Lingkungan Hidup. PermenLH No. 2 Tahun 2013. BN Tahun 2013 No. 314.

Indonesia. Peraturan Menteri Pertanian tentang Pedoman Perizinan Usaha Perkebunan. Permentan 98/Permentan/OT.140/9/2013. BN Tahun 2013 No. 1180. 